\title{
Pengaruh Proses Pengeringan Tradisional terhadap Komposisi Proksimat Nike Ikan Payangkah (Ophieleotris aporos) dari Danau Tondano
}

\author{
Sofie Satriani Krisen*, Ardi Kapahang \\ a Kimia, Universitas Negeri Manado, Tondano, 95619, Indonesia
}

INFO ARTIKEL

Diterima 06 Oktober 2019

Disetujui 27 Oktober 2019

\section{Key word:}

Payangkah fish nike,

proximate composition,

drying

\section{Kata kunci:}

Nike Ikan Payangkah,

proksimat,

pengeringan

\begin{abstract}
A B STRACT
The research on effect of traditional drying process againt proximate composition of the payangkah fish nike has been done. A number of payangkah fish nike samples has been taken from the Tondano lake, divided into two parts, i,e, fresh samples and other parts were traditionally dried at temperature range of $37^{\circ} \mathrm{C}$ for 24 hours. The proximate composition of wet and dried samples respectively specified was water content of $83.157 \%$, protein $13.128 \%$, lipid $1.48 \%$, ash $2.033 \%$, crude fiber $0.65 \%$ and carbohydrate $0.2 \%$. While for dry samples the water content of $9.59 \%$, protein $67.434 \%$, ash $5.065 \%$ and crude fiber $0.64 \%$. The results show that traditional drying process has positive influence against some parameters on proximate composition of the payangkah fish nike.
\end{abstract}

\begin{abstract}
A B S T R A
Penelitian tentang pengaruh proses pengeringan tradisional terhadap komposisi proksimat nike ikan payangkah telah dilakukan. Sejumlah sampel nike ikan payangkah diambil dari danau tondano, dibagi dua bagian yaitu bagian sampel segar dan bagian lainnya dikeringkan secara tradisional pada kisaran suhu $37^{\circ} \mathrm{C}$ selama 24 jam. Komposisi proksimat sampel basah dan kering yang ditentukan masing-masing adalah kadar air $83.157 \%$, protein $13.128 \%$, lipid $1.48 \%$, abu $2.033 \%$, serat kasar $0.65 \%$ dan karbohidrat $0.2 \%$. Sedangkan untuk sampel kering kadar air 9.591\%, protein $67.434 \%$, abu $5.065 \%$ dan serat kasar $0.64 \%$. Hasil penelitian menunjukkan bahwa proses pengeringan tradisional memiliki pengaruh positif terhadap beberapa parameter pada komposisi proksimat nike ikan payangkah.
\end{abstract}

\section{Pendahuluan}

Ikan merupakan sumber protein yang sangat penting pada diet manusia. Komposisi kimia daging ikan dapat bervariasi pada spesies ikan yang sama tergantung pada musim, umur, jenis kelamin dan habitat. Daging ikan umumnya mengandung empat bahan dasar dalam berbagai proporsi nutrisi utama seperti air $(70-80 \%)$, protein (18 - 20\%), lemak (5\%) dan mineral (5\%) serta nutrisi minor seperti vitamin, karbohidrat [1].

Danau Tondano merupakan habitat penting bagi berbagai jenis hewan dan tumbuhan diantaranya jenis ikan khas Sulawesi seperti ikan Payangka dan nike [2]. Nike ikan Payangkah merupakan ukuran kecil dari ikan payangkah dewasa yang pola makannya berbeda sehingga komposisi gizi juga berbeda. Nike ikan payangkah berukuran 10-35 mm dan ikan payangkah ukurannya $>35 \mathrm{~mm}$ bahwa selain kemampuan memanfaatkan makanan, ikan payangkah memiliki kemampuan reproduksi yang tinggi, kemampuan ini antara lain mampu memijah sepanjang tahun yang 
puncaknya pada bulan Juni, September dan Desember, dengan produksi telur rata-rata sekitar $30.000-60.000$ butir tiap individu [3]. Jenis ini mudah berkembang biak dan tidak banyak dimanfaatkan oleh penduduk sehingga sangatlah mendukung kelimpahannya selain akibat kemampuan adaptasi dan berkembang biak yang tinggi.

Metode pengeringan ikan sangat bervariasi tergantung pada jenis ikan yang digunakan dan produk yang diinginkan. Ikan mungkin akan terdehidrasi pada berbagai tingkat kelembaban dengan produk akhir mulai dari sekitar 10\% hingga $60 \%$. Suhu pengolahan dapat berkisar dari $5^{\circ} \mathrm{C}$ hingga $120^{\circ} \mathrm{C}$ dan pengolahan mulai dari setengah jam sampai beberapa bulan. Pengaruh metode pengolahan yang berbeda terhadap komposisi gisi spesies ikan yang berbeda telah banyak diteliti dan penelitian terhadap pengeringan ikan menggunakan sinar matahari $[4,5]$. Pengaruh metode memasak terhadap komposisi proksimat dan kandungan mineral dari rainbow trout (Oncorhynchus mykiss) telah dipelajari [6]. Pengolahan dan metode pengeringan yang berbeda memiliki pengaruh yang berbeda pula terhadap komposisi kimia ikan. Oleh karena itu kualitas ikan kering menggunakan metode yang berbeda tidak akan sama.

\section{Bahan dan Metode}

Dua puluh lima liter nike ikan Payangkah segar diperoleh dari petani ikan pinggiran danau tondano. Preparasi yang dilakukan meliputi penerimaan, pencucian, pemilihan selain ikan yang merupakan bahan ikutan (kotoran). Sebagian dari jumlah nike ikan payangkah digunakan untuk menentukan komposisi proksimat sampel segar dan sebagiannya lagi di keringkan pada suhu sekitar $37^{\circ} \mathrm{C}$ selama 24 jam selanjutnya ditentukan komposisi proksimatnya.

Komposisi proksimat dianalisis seperti yang dengan metode AOAC dimana semua bahan kimia yang digunakan adalah berkualitas analitis dan dikeluarkan oleh Sigma Co (St. Louis, USA) [7].

\section{Hasil dan Pembahasan}

Komposisi proksimat nike ikan payangkah segar dan kering disajikan pada Tabel 1. Setiap nilai dari parameter yang ditampilkan adalah merupakan nilai rata-rata dari perhitungan tiga kali ulangan. Sampel segar yang disajikan mempunyai kandungan rendah protein dan abu dibanding sampel kering. Sedangkan serat kasar baik sampel segar maupun kering jumlahnya hampir sama.

Tabel 1. Komposisi Proksimat segar dan kering nike ikan payangkah

\begin{tabular}{lcc}
\hline Komposisi proksimat & Segar & Kering \\
\hline Air $(\%)$ & 83.157 & 9.591 \\
\hline Abu $(\%)$ & 2.033 & 5.065 \\
\hline Protein $(\%)$ & 13.128 & 67.434 \\
\hline Serat Kasar $(\%)$ & 0.065 & 0.064 \\
\hline Lemak (\%) & 1.480 & - \\
\hline Karboidrat $(\%)$ & 0.202 & - \\
\hline
\end{tabular}

Kandungan air pada sampel segar diperoleh sebesar $83.157 \%$ dan sampel kering 9.591\% ini berarti terjadi penurunan kadar air sekitar $85 \%$ setelah dikeringkan. Umumnya kandungan kadar air ikan air tawar bervariasi antara $65 \%$ sampai $80 \%$ dari berat basah sampel dan sampel kering dapat menjadi $20 \%$ sampai $35 \%$ [8]. Pengeringan bahan terjadi karena adanya penguapan air ke udara yang diakibatkan oleh perbedaan kandungan uap air antara udara dengan bahan yang akan dikeringkan. Dalam hal ini, kandungan uap air udara lebih sedikit atau udara mempunyai kelembaban nisbi yang rendah sehingga terjadi penguapan. Pada proses pengeringan, kandungan air dapat diturunkan sampai 30\% sehingga aktifitas bakteri akan terhambat [9]. Dengan demikian kadar air yang diperoleh pada sampel kering ini kandungannya berada dibawah kadar air yang diisyaratkan SNI untuk ikan teri asin kering yaitu maksimal 20\% [10]. Gambar 1 merupakan gambaran proksimat dari nike ikan payangkah.

Berdasarkan hasil uji kandungan lemak, sampel nike ikan payangkah termasuk pada ikan jenis kandungan berlemak rendah $1.48 \%$ yaitu berada dibawah nilai yang di kategorikan, dimana kandungan lemak ikan terbagi atas 3 golongan yaitu ikan yang mempunyai kandungan lemak rendah $(<2 \%)$, ikan yang mempunyai kandungan lemak sedang $(2-5 \%)$ 
dan ikan yang mengandung lemak tinggi (4 5\%) [11]. Namun, kadar lemak ikan bervariasi antara kurang dari 5\% dan lebih dari 50\% pada sampel kering, dengan bertambahnya ukuran ikan kadar lemak dalam daging umumnya juga meningkat [12]. Nike ikan payangkah termasuk jenis ikan berukuran kecil sehingga hasil yang diperoleh dapat dinyatakan bahwa kandungan lemak ikan air tawar bervariasi tergantung pada spesies, ukuran dan makanannya [13].

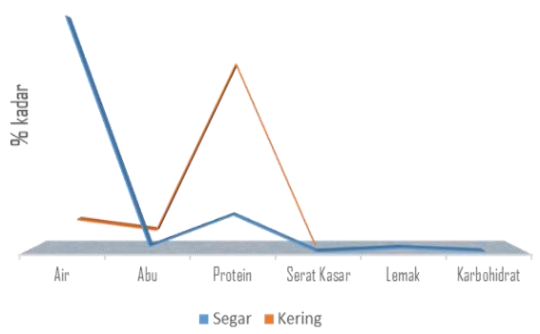

Gambar 1. Grafik proksimat nike ikan Payangkah.

Kadar total protein dari sampel kering adalah $67.43 \%$ sedangkan sampel segar hanya sebesar $13.12 \%$. Hal ini berarti terjadi peningkatan sebesar 55\% diatas kadar total protein sampel segar. Hasil yang diperoleh pada sampel segar ini tidak berbeda jauh dengan kandungan protein yang diperoleh pada ikan Goby yaitu 14.5\% [14]. Faktor penyebab perbedaan hasil kandungan protein sampel dalam bentuk segar dan kering adalah karena adanya kelebihan kandungan air pada sampel segar. Sebagian besar tubuh ikan mengandung banyak air. Sampel dalam bentuk segar masih mengandung air sedangkan sampel kering kadar airnya berkurang akibat proses pengeringan [15].

Kadar abu sampel segar diperoleh $2.033 \%$ dan setelah dikeringkan meningkat menjadi $5.065 \%$. Jika dibandingkan dengan hasil penelitian terhadap beberapa spesies ikan air tawar seperti pada ikan Gabus dan ikan Goby, maka kadar abu dari hasil penelitian ini berada sedikit diatasnya [14].

\section{Ucapan Terima kasih}

Peneliti menyampaikan terima kasih kepada Lembaga Penelitian Universitas Negeri Manado yang telah mendanai penelitian ini melalui Dana Dipa Unima Ta. 2015.
Secara umum, ada pengaruh yang signifikan dari proses pengeringan terhadap komposisi proksimat nike ikan payangkah. Pengaruh positif terhadap kadar air, protein dan abu.

\section{Daftar Pustaka}

1. Khurseed, J.; Mosharaff, Seasonal changes on biochemical composition of fresh water murrel Ophiocephalus punctatus (Bloch). Hydrobiologia 1998, 32: 206-213.

2. Suryadiputra I.N.N.; Ferry, H.; Ilman, M., Danau Tondano salah satu dari lima belas danau prioritas di Indonesia yang harus Segera dipulihkan fungsinya., Warta Konservasi Lahan Basah., 2010, 18 (2)

3. Soeroto, B., Makanan dan Reproduksi ikan payangka (Ophiocara aporos) di Danau Tondano., FPS, IPB. 1988.

4. Afolabi O.A.; Arawomo, A.O.; Oke, O. L., Quantity Changes of Nigeria Traditional Processed Freshwater Species I: Nutritive and Organoleptic Changes. J. Food Technol. 1984, 19: 333-340.

5. Bala, B.K.; Mondol, M.R.A., Experimental Investigation on Solar Drying of Fish Using Solar Tunnel Dryer. Drying Technol. 2001, 19: 427-436

6. Gokoglu, N.; Yerlikaya, P.; Cengiz. E., Effects of Cooking Methods on the Proximate Composition and Mineral Contents of Rainbow Trout (Oncorhynchus mykiss). Food Chem. 2004, 84: 19-22

7. AOAC., Official Methods of Analysis of The Association of Analytical Chemists, Washington, D.C. 2005.

8. Steffens, W.; Wirth, M., Süßwasserfisch gegen Bluthochdruck. Fischer und Teichwirt, 1999, 50: 85-87.

9. Moeljanto, Pengawetan dan Pengolahan Hasil Perikanan, Jakarta: Penebar swadaya, 1992.

10. BSN., Standarisasi Nasional Indonesia, Ikan teri asin kering, Jakarta: Badan Standarisasi Indonesia, 2009.

11. Winarno, F.G., Pangan Gizi, Teknologi dan Konsumen, Jakarta: Gramedia, 1993.

12. Steffens, W., Freshwater fish - wholesome foodstuffs. Bulg. J. Agric.Sci. 2006, 12: 320328

\section{Kesimpulan}


13. Steffens, W., Effects of variation in essential fatty acids in fish feeds on nutritive value of freshwater fish for humans. Aquaculture 1997,151: 87-119.

14. Wimalasena, S.; Jayasurya, M.N.S., Nutrient analysis of same fresh water fish, J.Natn.Sci.Foundation Sri Lanka 1996, 24 (1): 21-26.

15. Alfrianto, E., Pengawasan Mutu Bahan/Produk Pangan, Direktorat Pembinaan Sekolah Menengah Kejuruan, Direktorat Jenderal Manajemen Pendidikan Dasar dan Menengah, Departemen Pendidikan Nasional, 2008. 